\title{
PENINGKATAN SIKAP TANGGUNG JAWAB DAN KEMANDIRIAN BELAJAR MAHASISWA MELALUI METODE TUTORIAL DI JURUSAN PENDIDIKAN GEOGRAFI
}

\author{
Muhammad Nursa'ban \\ FIS Universitas Negeri Yogyakarta \\ email: mnsaban@yahoo.com
}

\begin{abstract}
Abstrak: Penelitian ini bertujuan meningkatkan sikap tanggung jawab dan kemandirian mahasiswa menggunakan metode tutorial dengan Penelitian Tindakan Kelas. Subjek penelitian yaitu 60 mahasiswa kelas Nonreguler yang mengambil mata kuliah Strategi Pembelajaran Geografi tahun ajaran 2012/2013. Data dikumpulkan melalui angket dan observasi kemudian dianalisis secara univariat. Keberhasilan tindakan ditunjukkan oleh setidaknya $70 \%$ mahasiswa mengalami peningkatan sikap tanggung jawab dan kemandirian dalam kategori baik. Hasil diperoleh dari peningkatan persentase setiap aspek pada kondisi awal, siklus 1, dan siklus 2. Rata-rata sikap tanggung jawab yaitu $81 \%$ atau 49 mahasiswa dengan selisih 14\% dari siklus 1 dan 39\% dari kondisi awal. Hasil sikap kemandirian diperoleh rata-rata $79 \%$ atau 47 mahasiswa dengan selisih sebesar $16 \%$ dari siklus 1 dan $32 \%$ dari kondisi awal.
\end{abstract}

Kata Kunci: tanggung jawab, kemandirian, tutorial, geografi

\section{IMPROVING STUDENTS' RESPONSIBILITY AND LEARNING AUTONOMY BY THE TUTORIAL METHOD AT DEPARTMENT OF GEOGRAPHY EDUCATION}

\begin{abstract}
This study aimed to investigate the improvement of students' responsibility and learning autonomy by the tutorial method using Classroom Action Research. The subjects were 60 non-regular students taking the Geography Learning Strategies course in the academic year of 2012/2013. The data were collected through questionnaires and observation and analyzed using univariate. The indicators of success were that at least $70 \%$ of the students improved their responsibility and autonomy into the good category. The findings showed an increase in the percentage of every aspect in the initial conditions, cycle 1 and cycle 2 . The average attitude of responsibility was $81 \%$ or 49 students with a difference of $14 \%$ of cycle 1 and $39 \%$ of the initial conditions. The mean of learning autonomy was $79 \%$ or 47 students with a difference of $16 \%$ of cycle 1 and $32 \%$ of the initial condition.
\end{abstract}

\section{Keywords: responsibility, autonomy, tutorials, Geography}

\section{PENDAHULUAN}

Keberhasilan pendidikan dapat diwujudkan salah satunya melalui ketepatan proses pembelajaran dalam mencapai tujuan pembelajaran tersebut. Proses pembelajaran dilakukan dengan berbagai variasi program yang disesuaikan dengan kebutuhan pembelajar, kurikulum, dan kebijakan institusi pendidikan. Pada jenjang perguruan tinggi, Menteri Pendidikan Nasional mengatur tentang kurikulum melalui Surat Keputusan Nomor 045/U/2002 yang menyatakan bahwa kurikulum pendidikan tinggi berbasis pada kompetensi dan tidak lagi berorientasi materi saja. Oleh karena itu, proses pem- belajaran yang dikembangkan selayaknya mendukung kebutuhan mahasiswa dan kompetensi yang harus dicapai.

Salah satu bentuk proses perkuliahan yang dianggap relevan yaitu dengan menerapkan model pembelajaran berbasis masalah atau lebih dikenal istilah Problem Based Learning (PBL). Dijelaskan Harsono dan Dwiyanto (2005: 36) bahwa PBL berpusat pada aktivitas siswa (student centered) dan kehidupannya bertumpu pada proses tutorial. Metode pembelajaran tutorial dianggap mampu meningkatkan keaktifan dan partisipasi mahasiswa dalam belajar, serta pelibatan mahasiswa secara aktif diharapkan 
mampu menjadi bekal untuk melakukan kegiatan belajar secara mandiri (Widuroyekti, 2006: 55-65).

Salah satu teknik pembelajaran dari metode tutorial yang dikembangkan oleh Moust, Bouhuijs, dan Schmidt (2007:35-65) yaitu menggunakan tujuh langkah (seven jumps) yang pada hakikatnya menempatkan peran dan tanggung jawab pembelajar (mahasiswa) lebih besar dan sangat penting. Metode ini mengedepankan kemandirian dan tanggung jawab yang besar dari pembelajar sehingga mereka membiasakan diri dalam memupuk ranah afektif yang berorientasi pada nilai karakter. Implementasi dari metode tutorial menempatkan peran dan tanggung jawab pembelajar (mahasiswa) memperoleh pengalaman sebagai pemimpin kelompok, sekretaris diskusi, dan anggota kelompok yang bertanggung jawab atas keberhasilan diskusi dalam pencapaian tujuan pembelajaran (Harsono, dkk, 2005:8)

Pengamatan penulis selama proses pembelajaran dalam mata kuliah Strategi Pembelajaran Geografi sering dijumpai mahasiswa yang kesulitan berpartisipasi sebagai wujud tanggung jawab pembelajar dalam mengikuti perkuliahan. Mereka nampak kesulitan merumuskan gagasan, belum berani menyampaikan pendapat, dan belum biasa bersaing dalam menyampaikan pendapat dengan teman lain. Penguatan atau pemaparan dari dosen menjadi tumpuan pengetahuan mahasiswa. Mereka sering belum mampu menangkap inti dari permasalahan dan merumuskan tujuan pembelajaran. Misalnya pada saat diskusi kasus, hasilnya tidak sesuai dengan yang diharapkan. Gagasan yang keluar terbatas pada satu referensi saja bahkan terkadang kesulitan menemukan pustaka yang menunjang, belum dapat memaknai tema diskusi dan terbatas hanya hafalan semata. Permasalahan lain yang diperoleh yaitu delapan dari sepuluh orang mahasiswa yang ditanya penulis menyatakan bahwa mereka merasa malas ketika mencari sumber atau referensi buku, dan mereka lebih senang jika diberikan catatan secara langsung oleh dosen.

Berdasarkan permasalahan di atas, maka penulis berasumsi perlu dilakukan perubahan dalam proses pembelajaran yang lebih menekankan tanggung jawab dan kemandirian mahasiswa. Oleh karena itu, penulis melakukan kajian dengan merumuskan masalah yang diangkat yaitu; "Bagaimana penerapan metode tutorial dapat meningkatkan sikap tanggung jawab dan kemandirian mahasiswa Jurusan Pendidikan Geografi?".

\section{METODE}

Kajian ini menggunakan jenis Penelitian Tindakan Kelas (PTK) yang dikembangkan Kemmis dan Taggart (1988) dengan empat tahapan kegiatan pada setiap siklus yaitu: (1) perencanaan, (2) pelaksanaan, (3) observasi, dan (4) refleksi. Aspek tanggung jawab diteliti melalui indikator: (1) keterlibatan mahasiswa dalam metode tutorial; (2) kemauan mahasiswa untuk merespon dan berkreasi dalam pembelajaran; (3) menghargai proses diskusi; (4) keterampilan komunikasi; (5) tanggung jawab; dan (6) kesadaran diri/ evaluasi diri. Indikator dari aspek kemandirian yaitu: (1) cara memulai belajar; (2) mengatur waktu belajar; (3) menggunakan gaya belajar sendiri; (4) mampu berfikir secara kritis, kreatif dan inovatif; (5) tidak mudah terpengaruh oleh pendapat orang lain; (6) tidak lari atau menghindari masalah; (7) memecahkan masalah dengan berfikir yang mendalam; (8) apabila menjumpai masalah dipecahkan sendiri tanpa bantuan orang lain; (9) tidak merasa rendah diri apabila harus berbeda dengan orang lain; (10) berusaha bekerja dengan penuh ketekunan dan kedisiplinan; dan (11) bertanggung jawab atas tindakannya sendiri.

Tindakan yang digunakan pada metode tutorial ini menggunakan tujuh langkah (seven jumps) dari Schmidt dan Bouhuijs (2007:35-38) yaitu: (1) klarifikasi terminologi dan konsep yang belum dipahami; (2) mendefinisikan permasalahan; (3) menganalisis permasalahan dan menawarkan penjelasan sementara; (4) menginventarisir berbagai penjelasanan yang dibutuhkan; (5) menformulasi tujuan belajar; (6) mengumpulkan informasi melalui belajar mandiri; (7) mensintesis informasi baru dan menguji serta mengevaluasinya untuk permasalahan 
yang sedang dikemukakan dan melakukan refleksi penguatan hasil belajar.

Subjek penelitian ini yaitu seluruh mahasiswa kelas non reguler semester yang mengambil mata kuliah Strategi Pembelajaran Geografi (SPG) pada tahun ajaran 2012/2013 berjumlah 60 orang. Teknik pengumpulan data menggunakan angket, dan observasi dengan instrumen menggunakan skala data ordinal dalam empat kategori yaitu sangat baik, baik, cukup, dan kurang baik. Pengisian kedua instrumen menggunakan jawaban 1, 2, 3, atau 4. Data yang diperoleh dari hasil pengukuran dideskripsikan secara kuantitatif dan diklasifikasikan menjadi beberapa kategori, yaitu sebagai berikut.

$$
\begin{array}{ll}
>(\mathrm{Mi}+1,5 \mathrm{SBi}) & \text { :sangat baik } \\
\mathrm{Mi}-(\mathrm{Mi}+1,5 \mathrm{SBi}) & : \text { baik } \\
(\mathrm{Mi}-1,5 \mathrm{SBi})-\mathrm{Mi} & \text { :cukup } \\
<(\mathrm{Mi}-1,5 \mathrm{SBi}) & \text { :kurang baik }
\end{array}
$$

Keberhasilan tindakan diukur dengan adanya peningkatan tanggung jawab dan kemandirian belajar mahasiswa ketika berlangsung pembelajaran menggunakan metode tutorial pada mata kuliah Strategi Pembelajaran Geografi. Peningkatan ini secara kuantitatif ditunjukkan oleh setidaknya $70 \%$ mahasiswa mengalami peningkatan aspek tanggung jawab dan kemandirian minimal kategori "baik".

\section{HASIL DAN PEMBAHASAN}

Penelitian ini telah dilaksanakan selama dua siklus dalam empat pertemuan. Setiap siklus terdiri atas dua kali pertemuan selama 150 menit atau setara 3 SKS. Selama pelaksanaan penelitian disampaikan dua Kompetensi Dasar (KD) yaitu "menganalisis pengembangan kurikulum SMA" dengan materi pokok "pengembangan kurikulum", dan KD "mendeskripsikan struktur kurikulum Mata Pelajaran Geografi” dengan materi pokok "struktur kurikulum mata pelajaran geografi". Masing-masing materi pokok diselesaikan dalam waktu 2 kali pertemuan. Sebelum diberikan tindakan pada siklus 1 . Penulis telah menyebarkan angket penilaian sejawat untuk mengukur kondisi awal tingkat tanggung jawab dan kemandirian subjek penelitian. Gambaran awa persentase sikap tanggung jawab dan kemandirian mahasiswa jurusan pen- didikan geografi kelas NR yang mengambil mata kuliah Strategi Pembelajaran Geografi ditunjukkan Tabel 1.

Pesersentase rata-rata sikap tanggung jawab mahasiswa yang mengambil mata kuliah Strategi Pembelajaran Geografi tahun ajaran 2012/2013 sebesar 42\%, atau baru sekitar 25 mahasiswa dari 60 mahasiswa memiliki sikap tanggung jawab yang baik atau sangat baik dalam mengikuti perkuliahan. Angka tersebut masih jauh dari kondisi yang diharapkan yaitu setidaknya $70 \%$ atau 42 mahasiswa sehingga penulis menjadikan data tersebut sebagai dasar memberikan tindakan dengan metode tutorial teknik seven jumps. Aspek-aspek penilaian mengenai sikap tanggung jawab ini dikembangkan dalam instrumen angket dan observasi dengan 19 pernyataan dalam angket dan dua pertanyaan observasi.

Data mengenai rata-rata hasil penilaian awal sikap kemandirian mahasiswa ditunjukkan Tabel 2. Persentase rata-rata sikap awal kemandirian mahasiswa, yaitu sebesar $47 \%$. Artinya, mahasiswa yang memiliki sikap kemandirian yang baik dalam pembelajaran masih kurang dari indikator keberhasilan, yaitu 70\%. Aspek penilaian "mampu berfikir secara kritis, kreatif dan inovatif" merupakan aspek yang memiliki skor paling rendah, yaitu $15 \%$ atau hanya dimiliki oleh sekitar 9 orang mahasiswa. Aspekaspek penilaian sikap kemandirian ini diperoleh melalui instrumen angket dan catatan observasi yang dikembangkan oleh penulis dan dinilai sebelum pemberian tindakan.

\section{Hasil Siklus I}

Pada tahap perencanaan penulis sebagai kolaborator mempersiapkan Rencana Pelaksanaan Pembelajaran (RPP) yang telah disisipkan langkah-langkah metode tutorial, angket penilaian sejawat, dan lembar observasi. Selain itu penulis menyiapkan kasus sebagai materi diskusi kelompok dan membentuk kelompok diskusi belajar dari 60 mahasiswa menjadi 6 kelompok, setiap kelompok terdiri atas 10 mahasiswa. 
Tabel 1. Persentase Hasil Penilaian Awal Sikap Tanggung Jawab

\begin{tabular}{llc}
\hline \multicolumn{1}{c}{ Variabel } & \multicolumn{1}{c}{ Aspek Penilaian } & $\%$ \\
\hline $\begin{array}{l}\text { 1. Tanggung } \\
\text { jawab }\end{array}$ & 1.1. Keterlibatan mahasiswa dalam metode Tutorial & 58 \\
& 1.2. Kemauan mahasiswa merespon dan berkreasi dalam metode Tutorial & 27 \\
& 1.3. Menghargai proses diskusi & 48 \\
& 1.4. Keterampilan Komunikasi & 30 \\
& 1.5. Tanggungjawab individu & 63 \\
& 1.6. Kesadaran diri/ evaluasi diri & 23 \\
\hline
\end{tabular}

Tabel 2. Persentase Hasil Penilaian Awal Sikap Kemandirian

\begin{tabular}{|c|c|c|}
\hline Variabel & Aspek Penilaian & $\%$ \\
\hline \multirow{12}{*}{$\begin{array}{l}\text { 2. Keman- } \\
\text { dirian }\end{array}$} & 2.1. Cara memulai belajar & 55 \\
\hline & 2.2. Mengatur Waktu belajar & 45 \\
\hline & 2.3. Menggunakan gaya belajar sendiri & 63 \\
\hline & 2.4. Mampu berfikir secara kritis, kreatif dan inovatif. & 15 \\
\hline & 2.5. Tidak mudah terpengaruh oleh pendapat orang lain. & 65 \\
\hline & 2.6. Tidak lari atau menghindari masalah. & 40 \\
\hline & 2.7. Memecahkan masalah dengan berfikir yang mendalam. & 32 \\
\hline & 2.8. Apabila menjumpai masalah dipecahkan sendiri tanpa bantuan orang lain. & 53 \\
\hline & 2.9. Tidak merasa rendah diri apabila harus berbeda dengan orang lain. & 35 \\
\hline & 2.10. Berusaha bekerja dengan penuh ketekunan dan kedisiplinan & 48 \\
\hline & 2.11. Bertanggung jawab atas tindakannya sendiri & 67 \\
\hline & Total rata-rata & 47 \\
\hline
\end{tabular}

Pelaksanaan tindakan pada siklus I pertemuan 1 dan 2 dilaksanakan masing-masing selama 150 menit. Kompetensi dasar pada siklus ini yaitu "menganalisis pengembangan kurikulum SMA" dengan materi pokok "pengembangan kurikulum". Pada pertemuan pertama, kolaborator menggunakan waktu 15 menit pertama untuk pengkondisian kelas dan apersepsi. Setelah itu, dilanjutkan mendeskripsikan langkah-langkah pelaksanaan teknik seven jumps kemudian kolaborator membagikan materi kasus diskusi kepada setiap kelompok. Mahasiswa menindaklanjuti kasus yang diberikan melalui tahapan seven jumps.

Pada pertemuan 50 menit pertama dilaksanakan langkah 1-5 dari tujuh langkah. Langkah keenam dan ketujuh dilakukan dalam 100 menit terakhir dengan kegiatan berupa pengumpulan informasi dari berbagai referensi melalui kajian pustaka dari referensi yang telah dipersiapkan setelah itu mensintesis informasi baru dan menguji serta mengevaluasinya untuk permasalahan yang sedang dikemukakan dan melakukan refleksi penguatan hasil belajar dilakukan setelah kegiatan pada langkah enam. Pada pertemuan kedua disampaikan hasil diskusi dan penguatan serta feedback dari dosen sekaligus melakukan refleksi kegiatan pertemuan pertama.

Hasil proses observasi dari tindakan yang dilakukan pada siklus I dideskripsikan untuk masing-masing variabel sebagai berikut.

\section{Tanggung Jawab Belajar}

Hasil penilaian pada variabel tanggung jawab belajar mahasiswa merupakan akumulasi persentase perolehan skor yang mendapat nilai kategori setidaknya "baik" atau lebih dari 52,5. Hasil penilaian terhadap aspek yang diamati terhadap tanggung jawab mahasiswa dalam pembelajaran ditunjukkan Tabel 3. 
Hasil penilaian terhadap sikap tanggung jawab pada siklus 1 berdasarkan penilaian observer dan sejawat terhadap enam aspek dari indikator tanggung jawab diperoleh rerata total $67 \%$, atau mengalami peningkatan $25 \%$ dari kondisi awal sebelum diberikan tindakan. Hasil proses pembelajaran menggunakan metode tutorial pada sikap tanggung jawab pada siklus 1 ini nampak bahwa aspek keterampilan komunikasi masih relatif rendah. Pada saat berlangsung pembelajaran mahasiswa cenderung pasif dan kesulitan terlibat berkomunikasi dalam perkuliahan, hanya beberapa mahasiswa saja yang turut terlibat.

\section{Kemandirian Belajar}

Kemandirian mahasiswa yang diimplementasikan dalam skenario metode tutorial dikembangkan dalam 11 aspek penilaian. Skor yang dihitung minimal kategori "baik" atau lebih dari 27,5. Ringkasan data persentase hasil penilaian kemandirian siklus 1 ditunjukkan Tabel 4.

Hasil penilaian aspek-aspek kemandirian pada siklus 1 diperoleh rerata total $63 \%$, atau mengalami peningkatan sekitar $16 \%$ dari kondisi awal sebelum diberikan tindakan. Rerata total yang diperoleh pada siklus ini belum mencerminkan dan mencapai indikator keberhasilan tindakan yang diharapkan yaitu minimal $70 \%$. Namun demikian dari 11 aspek kemandirian yang diukur terdapat 4 aspek atau sekitar 36.4\% telah mencapai $70 \%$ atau lebih.

Secara visual hasil penilaian variabel tanggung jawab pada siklus 1 ditunjukkan Gambar 1. Secara visual hasil penilaian variabel kemandirian pada siklus 1 ditunjukkkan pada Gambar 2. Data hasil penilaian kemandirian ditunjukkan bahwa aspek mampu berfikir secara kritis, kreatif dan inovatif, dan tidak merasa rendah diri apabila harus berbeda dengan orang lain menduduki persentase paling rendah yaitu $47 \%$.

Tabel 3. Persentase Hasil Penilaian Sikap Tanggung Jawab Siklus 1

\begin{tabular}{|c|c|c|}
\hline Variabel & Aspek Penilaian & $\%$ \\
\hline \multirow[t]{6}{*}{ Tanggung jawab } & 1. Keterlibatan mahasiswa dalam metode Tutorial & 75 \\
\hline & $\begin{array}{l}\text { 2. Kemauan mahasiswa merespon dan berkreasi } \\
\text { dalam metode Tutorial }\end{array}$ & 70 \\
\hline & 3. Menghargai proses diskusi & 63 \\
\hline & 4. Keterampilan Komunikasi & 55 \\
\hline & 5. Tanggungjawab individu & 75 \\
\hline & 6. Kesadaran diri/ evaluasi diri & 62 \\
\hline & rata-rata & 67 \\
\hline
\end{tabular}

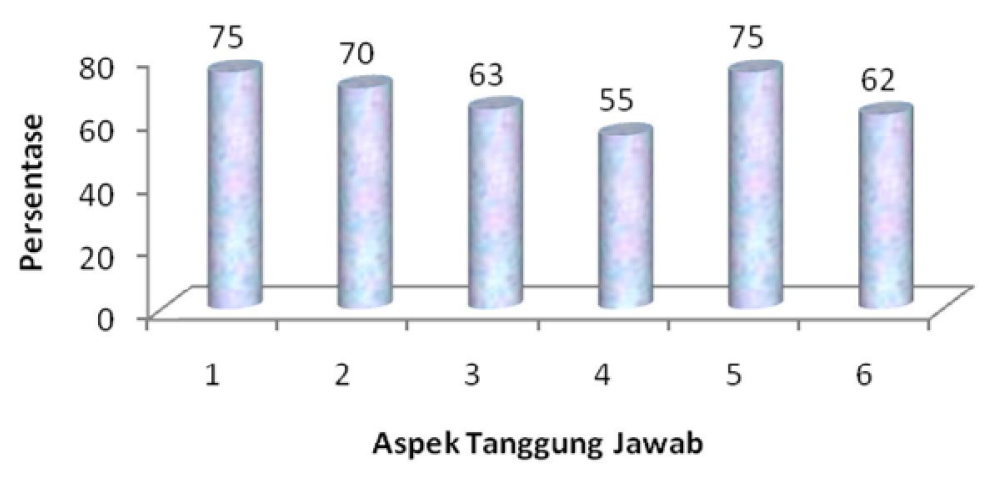

Gambar 1. Grafik Penilaian Tanggung Jawab Siklus 1 
Tabel 4. Persentase Hasil Penilaian Kemandirian Siklus 1

\begin{tabular}{|c|c|c|}
\hline Variabel & Aspek Penilaian & $\%$ \\
\hline \multirow[t]{12}{*}{ Kemandirian } & 1. Cara memulai belajar & 72 \\
\hline & 2. Mengatur Waktu belajar & 63 \\
\hline & 3. Menggunakan gaya belajar sendiri & 77 \\
\hline & 4. Mampu berfikir secara kritis, kreatif dan inovatif. & 47 \\
\hline & 5. Tidak mudah terpengaruh oleh pendapat orang lain. & 70 \\
\hline & 6. Tidak lari atau menghindari masalah. & 67 \\
\hline & $\begin{array}{l}\text { 7. Memecahkan masalah dengan berfikir yang } \\
\text { mendalam. }\end{array}$ & 55 \\
\hline & $\begin{array}{l}\text { 8. Apabila menjumpai masalah dipecahkan sendiri } \\
\text { tanpa bantuan orang lain. }\end{array}$ & 62 \\
\hline & $\begin{array}{l}\text { 9. Tidak merasa rendah diri apabila harus berbeda } \\
\text { dengan orang lain. }\end{array}$ & 47 \\
\hline & $\begin{array}{l}\text { 10. Berusaha bekerja dengan penuh ketekunan dan } \\
\text { kedisiplinan }\end{array}$ & 62 \\
\hline & 11. Bertanggung jawab atas tindakannya sendiri & 72 \\
\hline & Rata-rata & 63 \\
\hline
\end{tabular}

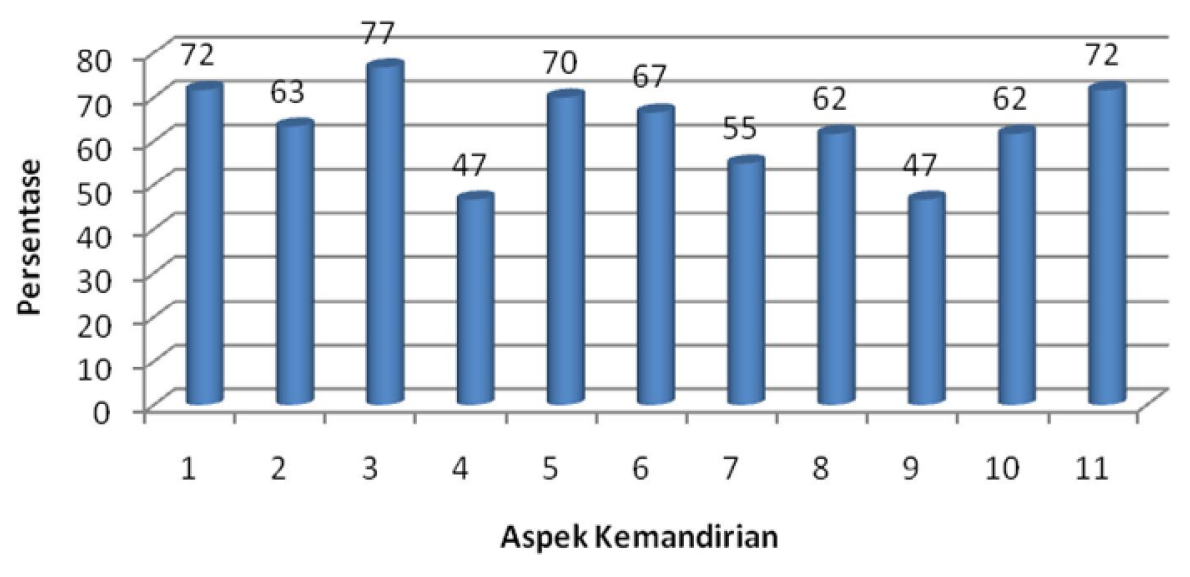

Gambar 2. Grafik Penilaian Kemandirian Siklus 1

Berdasarkan hasil catatan di lapangan yang dideskripsikan di atas dapat disinyalir bahwa telah terjadi peningkatan tanggung jawab mendasarkan atas 6 aspek penilaian. Rerata total telah mengalami peningkatan dari kondisi awal sebelum diberikan tindakan sebesar $25 \%$. Bahkan, terdapat tiga aspek atau sekitar $(50 \%)$ yang dapat mencapai lebih dari $70 \%$. Sikap kemandirian mengalami peningkatan dari hasil penilaian kondisi awal yaitu sekitar $16 \%$. Sementara itu, dari 11 aspek terdapat 4 aspek atau sekitar 36\% yang mencapai persentase lebih dari 70\%. Namun demikian, berdasarkan aspekaspek tanggung jawab yang diungkap pada pelaksanaan metode tutorial masih ditemukan kekurangan terutama pencapaian target keberhasilan indikator.

Ada sekitar tiga aspek yang perlu menjadi perhatian untuk ditingkatkan, yaitu sebagai berikut.

- Menghargai proses diskusi. Hasil pengamatan penulis selama pelaksanaan perkuliahan, diperkirakan mahasiswa menganggap proses diskusi merupakan kegiatan yang membe- 
baskan mereka untuk terlibat dalam perkuliahan, sehingga mahasiswa terkadang kurang bertanggung jawab dan menghargai ketentuan diskusi dalam metode tutorial. Mereka masih mengabaikan langkah-langkah yang sudah ditentukan dan cenderung melakukan diskusi seperi biasanya. Proses diskusi berlangsung ramai, tetapi tidak terarah. Pada saat diskusi berlangsung, beberapa aktivitas yang nampak dari mahasiswa antara lain: (1) belum mendengarkan dan memperhatikan apa yang sedang diutarakan oleh temannya dengan kesungguhan; (2) kurang menghargai nilai informasi dan sumbangan pikiran temannya; (3) belum dapat membedakan nilai informasi dari nilai personal.

- Keterampilan komunikasi belum optimal diperkirakan terkait beberapa hal antara lain: (1) kesulitan berbicara secara jelas dengan bahasa yang mudah dimengerti; (2) kesulitan menyatakan emosinya secara tepat dalam situasi tertentu; dan (3) sering menanggapi komunikasi non-verbal dari temannya.

- Kesadaran diri/evaluasi diri. Penulis mengamati beberapa hal yang menjadi kekurangan mahasiswa melakukan evaluasi diri atau kesadaran diri ini antara lain: (1) belum menyadari atas kelemahannya dan kekuatannya yang berkaitan dengan proses diskusi; (2) belum mau menerima kritik dari teman dengan mempertahankan diri dan cenderung menyalahkan orang lain; (3) belum mau untuk memperbaiki diri atas kritikan teman dalam konteks pembelajaran.

Aspek-aspek kemandirian yang diukur melalui siklus 1 , tampaknya masih diperlukan tindak lanjut. Dari 11 aspek yang diukur masih sekitar 7 aspek yang perlu peningkatan pada siklus berikutnya karena tingkat ketercapaiannya masih di bawah 70\%. Beberapa aspek kemandirian mahasiswa tersebut antara lain: (1) kesulitan mengatur waktu belajar; (2) cenderung sulit berfikir secara kritis, kreatif, dan inovatif; (3) cenderung mengabaikan masalah yang dianggap sulit oleh mereka, meskipun sudah diarahkan solusi yang diberikan; (4) kesulitan memecahkan masalah, dikarenakan keengganan berfikir yang mendalam; (5) cenderung me- mecahkan masalahnya sendiri tanpa bantuan orang lain sehingga apa yang menjadi jawabannya tidak sesuai dengan kesimpulan kelompoknya; (6) merasa rendah diri apabila harus berbeda dengan orang lain sehingga apa yang disampaikan temannya sering diikuti meskipun tidak sesuai dengan konteks permasalahan diskusi; dan (7) belum berusaha bekerja dengan penuh ketekunan dan kedisiplinan.

Berdasarkan hasil proses dan refleksi, maka penulis memutuskan beberapa langkah tindak lanjut yaitu: (1) menginformasikan beberapa kekurangan yang diperoleh dalam evaluasi di atas kepada mahasiswa dan diberitahu bahwa kekurangan tersebut belum mencerminkan aspek tanggung jawab dan kemandirian dalam pembelajaran; (2) menegaskan kembali tentang aturan pembelajaran menggunakan metode tutorial agar mengikuti aturannya; dan (3) memutuskan untuk menindaklanjuti dalam siklus berikutnya dengan menekankan perbaikan pada aspek-aspek yang belum mencapai kriteria yang diharapkan.

\section{Hasil Siklus 2}

Tahap perencanaan tindakan pada siklus 2 diawali dengan mempersiapkan Rencana Pelaksanaan Pembelajaran (RPP) yang telah disisipkan langkah-langkah metode tutorial, angket penilaian sejawat, dan lembar observasi, serta kasus sebagai materi diskusi. Setelah tahap perencanaan disiapkan dilanjutkan dengan tahap pelaksanaan dan observasi. Pelaksanaan tindakan siklus 2 relatif sama dengan pelaksanaan pada siklus 1 dengan kompetensi dasar yang dipelajari "mendeskripsikan struktur kurikulum Mata Pelajaran Geografi”, materi pokok "struktur kurikulum mata pelajaran geografi". Pada siklus ini, penulis menekankan beberapa catatan refleksi yang harus diperbaiki dari hasil pada saat berlangsung siklus 1 .

Hasil proses tindakan pada siklus 2 dideskripsikan sebagai berikut.

\section{Tanggung Jawab Belajar}

Hasil penilaian terhadap aspek tanggung jawab oleh mahasiswa dan observasi dalam perkuliahan menggunakan metode tutorial 
ditunjukkan Tabel 5. Jadi, hasil penilaian sikap tanggung jawab pada siklus 2 memperoleh rerata total $81 \%$, atau mengalami peningkatan sekitar $14 \%$ dari hasil penilaian siklus pertama. Data ini menggambarkan bahwa pada siklus dua, tanggung jawab mahasiswa dalam pembelajaran telah mencapai indikator keberhasilan tindakan yang diharapkan. Hasil penilaian pada siklus 2 terhadap aspek tanggung jawab secara keseluruhan telah melebihi $70 \%$ yang memperoleh kategori baik. Berdasarkan hasil penilaian tersebut dapat digambarkan bahwa metode tutorial memberikan kontribusi terhadap peningkatan tanggung jawab belajar mahasiswa. Berdasarkan tabel 5 digambarkan bahwa terdapat 4 aspek yang lain masih di sekitar antara $70 \%-80 \%$. Aspek dengan penilaian terendah masih relatif sama dengan siklus 1 yaitu keterampilan komunikasi dan kesadaran diri/ evaluasi diri.

Hasil proses tindakan melalui pembelajaran tutorial terhadap sikap tanggung jawab pada siklus dua menggambarkan bahwa terda- pat keberhasilan upaya peningkatan sikap tanggung jawab yang ditunjukkan persentase yang diperolehnya. Pembelajaran tutorial melalui tujuh tahapan tersebut mereflesikan langkah yang relatif tepat sebagai salahsatu wahana peningkatan sikap tanggung jawab mahasiswa.

\section{Kemandirian Belajar}

Hasil penilaian terhadap aspek-aspek kemandirian pada siklus 2 diperoleh rerata total $79 \%$, atau mengalami peningkatan $16 \%$ dari kondisi pada siklus 1. Data pada tabel 6 menggambarkan bahwa dari 11 aspek kemandirian yang diukur terdapat 5 aspek yang mencapai lebih dari $80 \%$ dan 6 aspek lainnya kurang dari $80 \%$, tetapi lebih dari $70 \%$. Rerata total yang diperoleh pada siklus ini telah mencerminkan dan mencapai indikator keberhasilan tindakan yang diharapkan yaitu minimal $70 \%$.

Secara visual hasil penilaian variabel kemandirian pada siklus 2 ditunjukkan pada Grafik 4.

Tabel 5. Persentase Hasil Penilaian Sikap Tanggung Jawab Siklus 2

\begin{tabular}{crlr}
\hline Variabel & \multicolumn{1}{c}{ Aspek Penilaian } & \% \\
\hline Tanggung jawab & 1. & Keterlibatan mahasiswa dalam metode Tutorial & 93 \\
& 2. & Kemauan mahasiswa merespon dan berkreasi \\
& & dalam metode Tutorial & 77 \\
& 3. & Menghargai proses diskusi & 78 \\
& 4. & Keterampilan Komunikasi & 72 \\
& 5. & Tanggungjawab individu \\
& 6. & Kesadaran diri/ evaluasi diri & 97 \\
\hline & \multicolumn{1}{c}{ rata-rata } & 72 \\
\hline
\end{tabular}

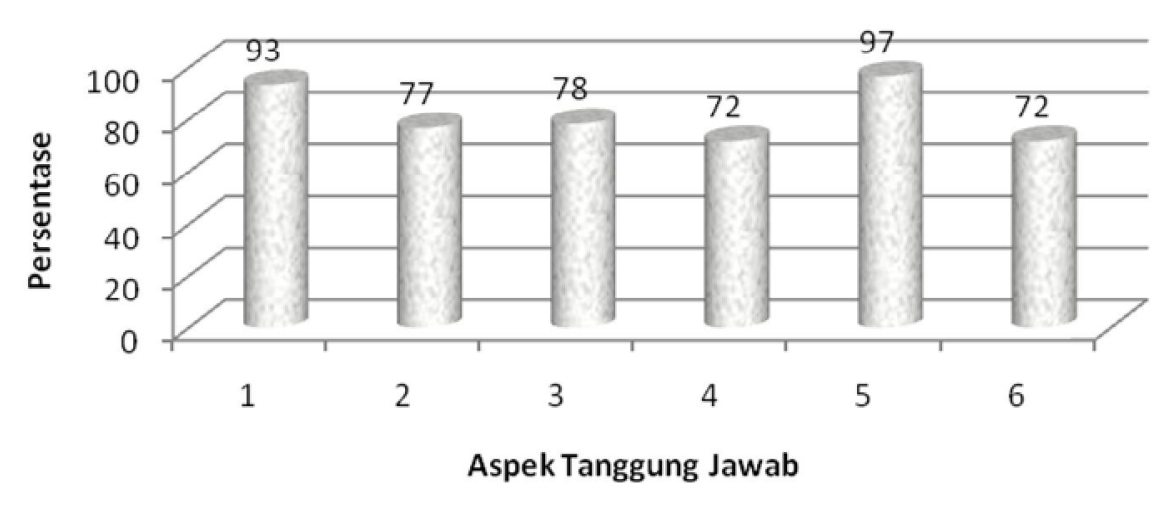

Gambar 3. Grafik Penilaian Sikap Tanggung Jawab Siklus 2 
Tabel 6. Persentase Hasil Penilaian Kemandirian Siklus 2

\begin{tabular}{lll}
\hline Variabel & \multicolumn{1}{c}{ Aspek Penilaian } & \% \\
\hline Kemandirian & 1. Cara memulai belajar & 93 \\
& 2. Mengatur Waktu belajar & 75 \\
3. Menggunakan gaya belajar sendiri & 97 \\
4. Mampu berfikir secara kritis, kreatif dan inovatif. & 70 \\
5. Tidak mudah terpengaruh oleh pendapat orang lain. & 80 \\
6. Tidak lari atau menghindari masalah. & 85 \\
7. Memecahkan masalah dengan berfikir yang mendalam. & 70 \\
8. Apabila menjumpai masalah dipecahkan sendiri tanpa & 70 \\
& bantuan orang lain. & 72 \\
9. Tidak merasa rendah diri apabila harus berbeda dengan & \\
& orang lain. & 73 \\
10. Berusaha bekerja dengan penuh ketekunan dan & kedisiplinan & 82 \\
\hline
\end{tabular}

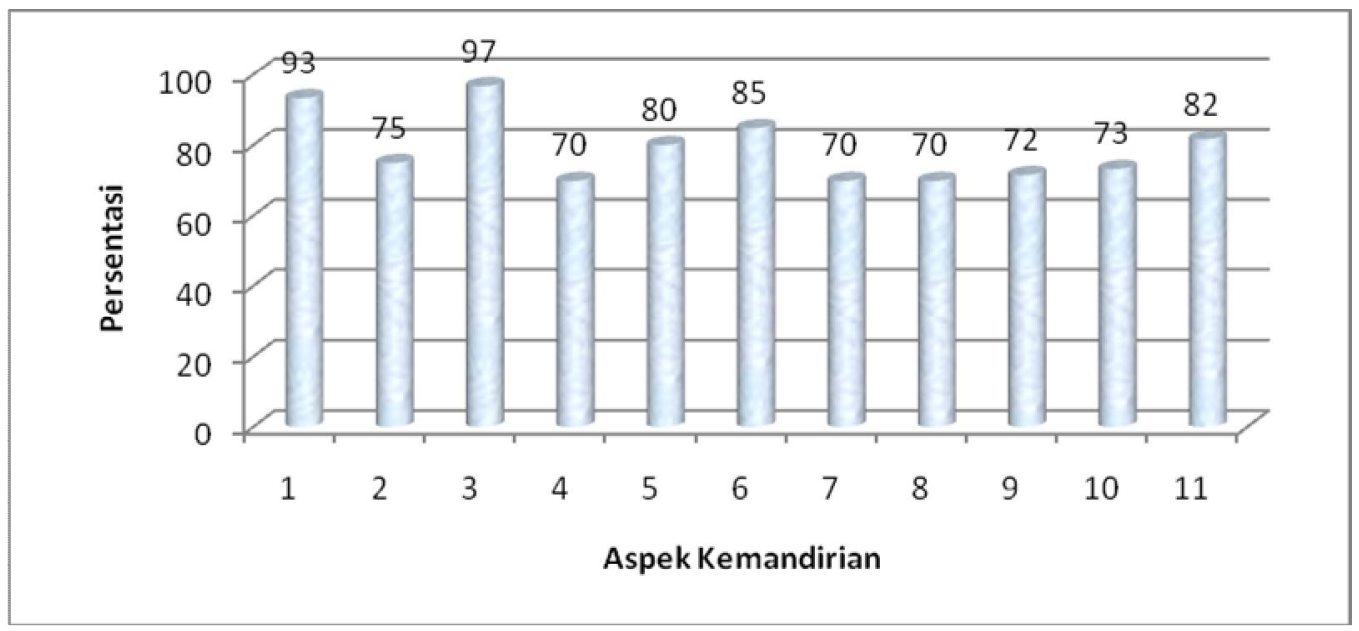

\section{Gambar 4. Grafik Penilaian Kemandirian Siklus 2}

Data hasil penilaian kemandirian yang disajikan gambar 4 menjelaskan bahwa tingkat kemandirian mahasiswa telah di atas $70 \%$. Data ini setidaknya menggambarkan bahwa metode pembelajaran tutorial melalui tujuh tahapannya tersebut menunjukkan kontribusi yang cukup efektif meningkatkan kemandirian mahasiswa. Sikap kemandirian mahasiswa turut terbentuk oleh ketentuan-ketentuan yang harus dilaksanakan dalam pembelajaran tuorial.

Hasil pengamatan menunjukkan bahwa mahasiswa melakukan kegiatan pembelajaran lebih bersungguh-sungguh terlibat dalam perkuliahan melalui penerapan metode tutorial.sikap tanggung jawab mengalami peningkatan dilihat dari perbandingan hasil penilaian antara kondisi awal, siklus pertama dan siklus kedua, mendasarkan 6 aspek tanggung jawab yang diukur diperoleh rerata total yang mengalami peningkatan. Adapun rerata total siklus 2 yaitu $81 \%$. Persentase tersebut lebih tinggi $14 \%$ dari siklus pertama sementara selisih dengan kondisi awal yaitu 39\%. Secara keseluruhan hasil penilaian terhadap 6 aspek tanggung jawab yang dinyatakan dalam 19 pernyataan dalam angket dan 3 dalam instrumen observasi telah mencapai lebih dari $70 \%$ untuk setiap aspeknya. 
Kemandirian mahasiswa dalam pembelajaran melalui penerapan metode tutorial pada siklus 2 mengalami peningkatan dari hasil penilaian kondisi awal dan siklus pertama dengan perolehan rerata total yaitu $79 \%$. Selisih peningkatan rerata total kemandirian hasil penilaian antara siklus 2 dengan siklus 1 yaitu sebesar $16 \%$, sementara selisih dengan kondisi awal yaitu $32 \%$. Hasil evaluasi ketercapaian target berupa peningkatan tanggung jawab dan kemandirian dalam perkuliahan Strategi Pembelajaran Geografi menggunakan metode tutorial pada siklus dua ditunjukkan pada Gambar 5.

Berdasarkan 6 aspek tanggung jawab yang diungkap pada perkuliahan metode tutorial dalam pencapaian target keberhasilan indikator tanggung jawab, ada empat aspek yang memiliki potensi dapat ditingkatkan lagi. Meskipun aspek-aspek tersebut telah mencapai rerata lebih dari $70 \%$ tetapi kondisinya masih di bawah $80 \%$ bahkan di bawah $75 \%$. Hal ini berbeda dengan dua aspek lainnya yang mampu mencapai persentase lebih dari $80 \%$. Penilaian aspek-aspek kemandirian pada siklus 2 diperoleh gambaran bahwa masih sebagian besar aspek perlu ditindaklanjuti karena belum mecapai $80 \%$, meskipun sudah melampaui batas rerata yang diharapkan yaitu $70 \%$.

Data-data yang diungkap sebelumnya menguatkan bahwa sikap tanggung jawab dan kemandirian belajar mahasiswa dapat dilakukan melalui pembelajaran menggunakan metode tutorial. Langkah-langkah yang dilalui dalam tutorial cenderung efektif dalam meningkatkan sikap tanggung jawab dan kemandirian. Berdasarkan hasil evaluasi pada tahap refleksi, maka aspek-aspek tanggung jawab dan kemandirian, rerata totalnya telah mencapai $70 \%$. Meskipun untuk beberapa aspek yang diungkap pada evaluasi kekurangan dapat tindak lanjuti melalui tindakan berikutnya. Atas dasar, hasil tindakan pada siklus 2 yang dijabarkan pada evaluasi ketercapaian target pada tahap refleksi, maka penulis memutuskan untuk menghentikan siklus karena indikator ketercapaian sudah terlampaui.

\section{Pembahasan}

Hasil penelitian yang menggambarkan adanya peningkatan sikap tanggung dan kemandirian merupakan salah satu keberhasilan perkuliahan ditinjau dari bentuk prestasi dan sikap (afektif) mahasiswa. Perkuliahan tersebut berlangsung dengan proses pembelajaran yang menerapkan metode pembelajaran secara baik. Hal ini mengindikasikan bahwa variasi tingkatan prestasi mahasiswa dipengaruhi juga oleh tanggung jawab dan kemandirian mereka dalam proses perkuliahan dan ketepatan dalam penggunaan metode pembelajaran.

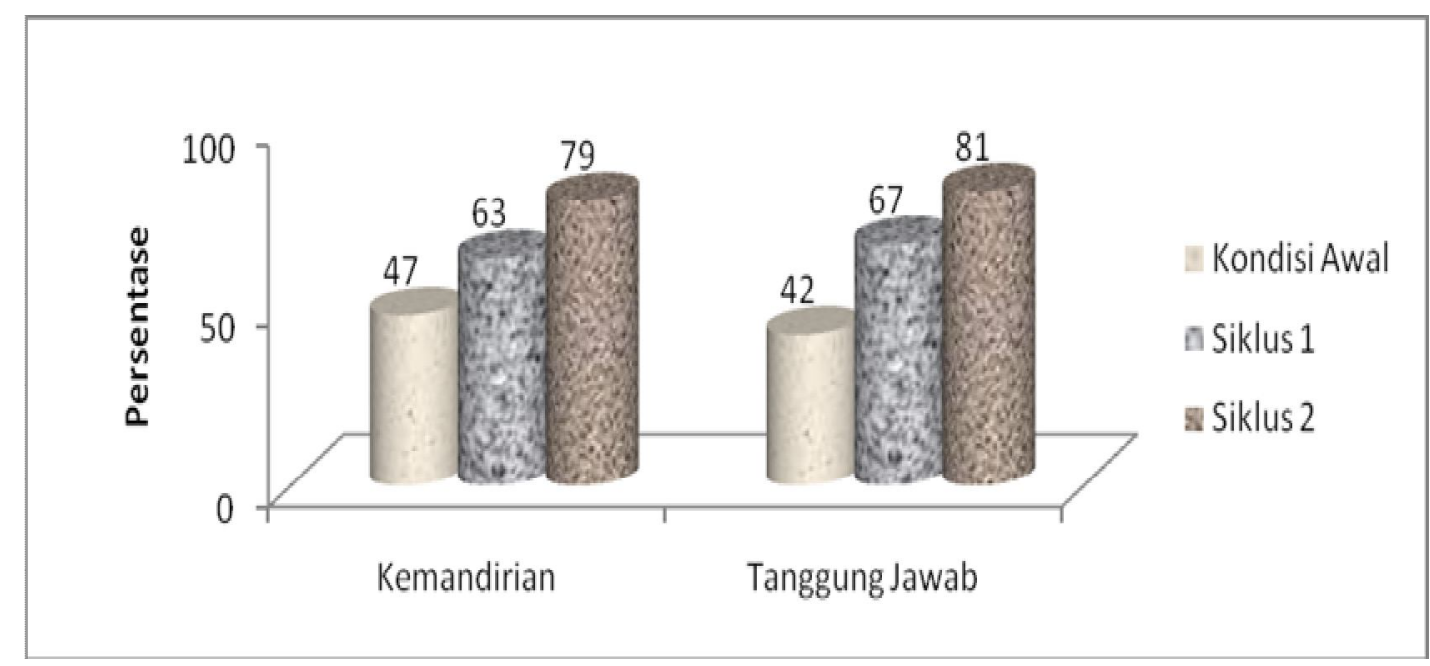

Gambar 5. Grafik Rerata Total Penilaian Variabel Tanggung Jawab dan Kemandirian pada Kondisi Awal, Siklus 1, dan Siklus 2 
Vanthournout (2013:33) menyatakan bahwa "A learning profile is conceived as the degree to which students use aspects of deep and surface approaches in their learning process and taking into account the dynamic interrelations...”. Definisi tersebut menggambarkan bahwa profil belajar dipahami dari tingkat keterlibatan siswa dari setiap aspek pendekatan proses belajar dari pemahaman biasa sampai mendalam sehingga dapat mengaitkan secara dinamis dengan aspek-aspek yang lain dalam kehidupan. Di pihak lain, Dimyati dan Mudjiono (2002:42-50) bahwa belajar sebagai suatu proses yang harus dipahami beberapa prinsipnya, antara lain: (1) perhatian dan motivasi, (2) keaktifan; (3) keterlibatan langsung/ berpengalaman; (4) pengulangan; (5) tantangan; (6) balikan dan penguatan. Selain itu, Dalyono (2002: 48-53) menjelaskan bahwa proses pembelajaran diharapkan mencapai beberapa tujuan antara lain: (1) perubahan perilaku; (2) mengubah kebiasaan; (3) mengubah sikap; (4) mengubah keterampilan; dan (5) menambah pengetahuan dalam berbagai bidang ilmu.

Dalam penelitian ini partisipasi mahasiswa sebagai bentuk tanggung jawab adalah keterlibatan mental dan emosi serta fisik mahasiswa dalam memberikan respon terhadap kegiatan yang dilaksanakan dalam proses pembelajaran serta mendukung pencapaian tujuan dan bertanggung jawab atas keterlibatannya. Berdasarkan pengertian di atas dapat diketahui bahwa dalam partisipasi terdapat unsur-unsur keterlibatan mahasiswa dalam segala kegiatan yang dilaksanakan dalam proses belajar mengajar dan kemauan mahasiswa untuk merespon dan berkreasi dalam kegiatan yang dilaksanakan dalam proses belajar mengajar. Harsono, dkk (2005:8-9) secara lebih terperinci mengemukakan tentang ciri-ciri pembelajar yang bertanggung jawab secara garis besar meliputi (1) menghargai proses diskusi; (2) keterampilan komunikasi; (3) tanggung jawab individu pembelajar; dan 4) kesadaran diri/ evaluasi diri.

Surya (2003:23) mengemukakan bahwa belajar mandiri adalah proses menggerakkan kekuatan atau dorongan dari dalam diri individu yang belajar untuk menggerakkan potensi diri- nya mempelajari objek belajar tanpa ada tekanan atau pengaruh asing di luar dirinya. Thoha (1996:123-124) membagi ciri kemandirian belajar dalam delapan jenis, yaitu :01) mampu berfikir secara kritis, kreatif dan inovatif, (2) tidak mudah terpengaruh oleh pendapat orang lain, (3) tidak lari atau menghindari masalah, (4) memecahkan masalah dengan berfikir yang mendalam, (5) apabila menjumpai masalah dipecahkan sendiri tanpa bantuan orang lain, (6) tidak merasa rendah diri apabila harus berbeda dengan orang lain (7) berusaha bekerja dengan penuh ketekunan dan kedisiplinan, dan (8) bertanggung jawab atas tindakannya sendiri.

Berdasarkan ringkasan tersebut dapat ditarik suatu catatan bahwa proses perkuliahan dengan paradigma pendidikan berpusat kepada mahasiswa merupakan kegiatan yang harus dilakukan dalam proses pembelajaran seperti penggunaan metode tutorial dalam penelitian ini. Prinsip pokok tutorial adalah "kemandirian mahasiswa" (student's independency) dan partisipasi sebagai wujud tanggung jawab pembelajar. Secara konseptual tutorial berbeda dengan kuliah (lecturing) yang umum berlaku di perguruan tinggi secara tatap muka. Faktor-faktor yang dianggap berperan penting terhadap keberhasilan dalam tutorial yaitu peran mahasiswa berupa tanggung jawab dalam berpartisipasi dan kemandirin.

\section{PENUTUP}

Berdasarkan pembahasan dan tujuan penelitian dapat diambil kesimpulan bahwa sikap tanggung jawab dan kemandirian mahasiswa pada perkuliahan Strategi Pembelajaran Geografi dapat ditingkatkan melalui penggunaan pembelajaran metode tutorial. Bukti-bukti peningkatan sikap tanggung jawab dan kemandirian mahasiswa ditunjukkan persentase peningkatan setiap aspek pada siklus 1 , dan siklus 2. Peningkatan sikap tanggung jawab dalam kategori setidaknya "baik" oleh rata-rata $81 \%$ atau 49 mahasiswa sebesar $14 \%$ dari siklus 1 dan peningkatan 39\% dari kondisi awal. Peningkatan sikap kemandirian dalam kategori setidaknya "baik" oleh rata-rata $79 \%$ atau 47 
mahasiswa sebesar $16 \%$ dari siklus 1 dan peningkatan sebesar 32\% dari kondisi awal.

\section{UCAPAN TERIMA KASIH}

Penelitian ini tidak lepas dari bantuan berbagai pihak secara moril, tenaga, waktu maupun materil. Kami mengucapkan terima kasih kepada: (1) Universitas Negeri Yogyakarta, terutama Wakil Rektor I UNY yang telah memberikan kesempatan bagi peneliti untuk melaksanakan penelitian; (2) Redaktur dan $R e$ viewer Jurnal Cakrawala Pendidikan yang telah memuat hasil penelitian ini; (3) Semua pihak yang telah terlibat dalam penelitian ini.

\section{DAFTAR PUSTAKA}

Dalyono. M. 2002. Psikologi Pendidikan. Jakarta: PT. Rineka Cipta.

Dimyati dan Mudjiono. 2002. Belajar dan Pembelajaran. Jakarta: Rineka Cipta

Harsono dan Dwiyanto, Djoko. 2005. "Pembelajaran Berpusat Mahasiswa", Kumpulan Naskah Pembelajaran Pusat Pengembangan Pendidikan UGM. Yogyakarta: Aditya Media Yogyakarta Bekerjasama dengan PPP UGM.
Hendra, Surya. 2003. Kiat Mengajak Anak Belajar dan Berprestasi. Jakarta:PT. Gramedia.

Jos Moust, P. Bouhuijs, Hans Schmidt. 2007. Introduction to Problem-Based Learning. Taylor \& Francis.

Kemmis, S. dan R. Mc Taggart. 1988. The Action Research Planner. Victoria: Deakin University.

Thoha, Chabib. 1996. Kapita Selekta Pendidikan Islam. Yogyakarta: Pustaka Pelajar.

Vanthournout, Gert. Et.all. 2013. "Assessing Students' Development in Learning Approaches According to Initial Learning Profiles: A Person-Oriented Perspective", dalam Jurnal Studies in Educational Evaluation, edisi 39. hlm. 33-40

Widuroyekti, Barokah. 2006. "Pendekatan Belajar Aktif dan Peningkatan Tanggung Jawab Mahasiswa dalam Proses Tutorial Tatap Muka". Jurnal Pendidikan, Volume 7, Nomor 1, hlm. 55 - 65. 